\title{
The Nature of the \\ Electron-transparent Zone that Surrounds Mycobacterium lepraemurium inside Host Cells
}

\author{
By P. DRAPER AND R. J. W. REES \\ National Institute for Medical Research, Mill Hill, London, $\mathrm{NW}_{7}$ I $A A$
}

(Received I2 February 1973)

SUMMARY

Liver and spleen tissue from mice infected 4 to 5 months previously with Mycobacterium lepraemurium has been examined in the electron microscope by negative staining, freeze-etching and ultrathin sectioning. Part or all of the electrontransparent zone seen around sectioned bacteria is composed of parallel fibrils wrapped longitudinally around the bacteria. It was isolated from homogenates of infected livers and spleens using urea density gradients and contained a mycoside of type C, a peptidoglycolipid known to occur in some other species of mycobacteria. The mycoside therefore forms a capsule around the bacterium to protect and insulate it from the host cell and its lysosomes.

\section{INTRODUCTION}

Yamamoto, Nishiura, Harada \& Imaeda (I 958a) first described the appearance of mouse tissues infected with the obligately intracellular pathogen Mycobacterium lepraemurium when examined as ultrathin sections in the electron microscope. The bacteria occurred inside vacuoles in phagocytic cells; between the membrane of the vacuole and the bacterium was a conspicuous 'electron-transparent zone'.

Brown \& Draper (1970) pointed out that in cultured fibroblasts containing multiplying Mycobacterium lepraemurium the electron-transparent zone often separated bacteria from lysosomal material in phagolysosomes, which seemed to be favourable sites for bacterial multiplication. Draper \& Rees (1970) described a fibrillar material which surrounded negatively stained $M$. lepraemurium gently removed from tissues of infected mice, and suggested that this was the substance of the clear space, whose function was to protect the bacteria from the lysosomal products of the host cell.

This paper describes in more detail the appearance of the fibrillar material, and techniques for isolating it and identifying it as a mycoside, a mycobacterial peptidoglycolipid. The use of freeze-etching has helped to confirm the identity of the electron-transparent zone, seen in ultrathin sections, with the fibrils demonstrated by negative staining.

\section{MITHODS}

Infected animals. Albino mice, Parkes strain, were infected intravenously with a suspension of Mycobacterium lepraemurium, which is maintained in our laboratory by mouse passage (Rees, Valentine \& Wong, 1960). After 4 to 5 months, visibly sick animals were killed and their livers and spleens removed. Material for electron microscopy was taken at once; otherwise the tissues were stored at $-20{ }^{\circ} \mathrm{C}$. 


\section{Electron microscopy}

Ultrathin sections. Small blocks of liver and spleen were fixed in $2.5 \%(\mathrm{v} / \mathrm{v})$ gluteraldehyde in Kellenberger buffer, $\mathrm{pH}_{7}$ (Kellenberger, Ryter \& Séchaud, 1958) for $16 \mathrm{~h}$ at $4{ }^{\circ} \mathrm{C}$, post-fixed in $\mathrm{I} \% \mathrm{OsO}_{4}$ in the same buffer, block-stained in $0.5 \%$ uranyl acetate in Kellenberger buffer, $\mathrm{pH}$ 6, dehydrated with acetone and embedded in Taab Embedding Resin (Taab Laboratories Ltd, Reading, Berkshire). Silver sections were cut with a Porter-Blum microtome or an LKB Ultrotome I, stained with $2 \%(\mathrm{w} / \mathrm{v})$ uranyl acetate and examined in a Philips EM 300 microscope operated at $60 \mathrm{kV}$.

Negative staining. Material was removed from infected livers with a sterile needle and floated on the surface of distilled water before being picked up on to formvar- and carboncoated grids. Stains used were: $2 \%(\mathrm{w} / \mathrm{v})$ uranyl acetate, $2 \%(\mathrm{w} / \mathrm{v})$ sodium silicotungstate, $\mathrm{pH} 7$, and $2.5 \%(\mathrm{w} / \mathrm{v})$ ammonium molybdate. Fractions obtained during the preparation of fibrillar material were transferred to coated grids and treated with the same negative stains.

Freeze-etching. Small blocks of infected liver were soaked for $16 \mathrm{~h}$ in $30 \%(\mathrm{v} / \mathrm{v})$ glycerol in $0.1 \mathrm{M}$-cacodylate buffer, $\mathrm{pH} 7.4$. In some cases blocks were first fixed for $\mathrm{I} h$ in $5 \%(\mathrm{v} / \mathrm{v})$ glutaraldehyde in the same buffer. Freeze-etching was carried out in a Balzers BAF 300 machine; samples were etched for $3 \mathrm{~min}$, shadowed with platinum-carbon for $6 \mathrm{~s}$ and coated with carbon for $8 \mathrm{~s}$. The replicas were cleaned overnight with domestic 'bleach' (sodium hypochlorite solution), followed by $70 \%(\mathrm{v} / \mathrm{v}) \mathrm{H}_{2} \mathrm{SO}_{4}$ for 2 to $3 \mathrm{~h}$. They were then mounted on grids and rinsed with chloroform to remove bacterial lipid before examination.

Preparation of fibrillar material. Livers and spleens from up to 100 mice were homogenized in a Potter-Elvehjem homogenizer (small batches) or an M.S.E. Atomix (M.S.E. Ltd, Crawley, Sussex) in cold $0.3 \mathrm{M}$-sucrose buffered with $2.5 \mathrm{~mm}$-potassium EDTA to pH 7.2. The supernatant, after centrifuging at $10000 \times g$ for $10 \mathrm{~min}$ to remove bacteria (Draper, I97I), was centrifuged at $30000 \times g$ for $\mathrm{I} h$. The sediment was washed in $0 \cdot \mathrm{I}$ M-tris buffer, $\mathrm{pH} 7 \cdot 2$, and resuspended in $8 \mathrm{M}$-urea in the same buffer. The suspension was overlaid with $6 \mathrm{M}-, 4 \mathrm{M}$ - and $2 \mathrm{M}$-urea and centrifuged at $20000 \times g$ in a swing-out rotor (Sorvall $\mathrm{HB}_{4}$ ) for 2 to $4 \mathrm{~h}$. The opalescent material in the upper layers of the gradients was removed, washed in $0.05 \%$ Tween 80 , then in water and freeze-dried.

\section{Analytical methods}

Carbohydrates. Fibrillar material was hydrolysed with $2 \mathrm{~N}-\mathrm{H}_{2} \mathrm{SO}_{4}$ for $2 \mathrm{~h}$ at $105{ }^{\circ} \mathrm{C}$. The acid was removed with $\mathrm{BaCO}_{3}$, and total carbohydrates estimated by the method of Dubois, Gilles, Hamilton, Rebers \& Smith (1956). Methyl pentoses were estimated by Dische's reaction (Dische, I962). Rhamnose was used as a standard for both estimations. Individual monosaccharides were detected on Merck cellulose thin-layer plates (E. Merck, Darmstadt, W. Germany), using the following solvents: $n$-butanol + pyridine + water $(6: 4: 3$, by vol), ethyl acetate + acetic acid + water $(3: 1: 3$, by vol), $n$-butanol + ethanol + water $(5: 1: 4$, by vol; upper phase).

Amino acids. Material was hydrolysed with $4 \mathrm{~N}-\mathrm{HCl}$ for $16 \mathrm{~h}$ at $105{ }^{\circ} \mathrm{C}$. Lipid was removed by extracting with ether, and the aqueous layer was then dried in vacuo over $\mathrm{NaOH}$. Compounds were detected by two-way chromatography on cellulose thin-layer plates using as solvents: $n$-butanol + acetic acid + water $(4: \mathrm{I}: \mathrm{I}$, by vol) followed by ethyl acetate + pyridine + acetic acid + water $(5: 5: \mathrm{I}: 3$, by vol $)$. Threonine and allothreonine were distinguished using $n$-butanol + acetone + water + aq. $\mathrm{NH}_{3}$ (sp. gr. 0.880) (8:1:6:1, by vol; 

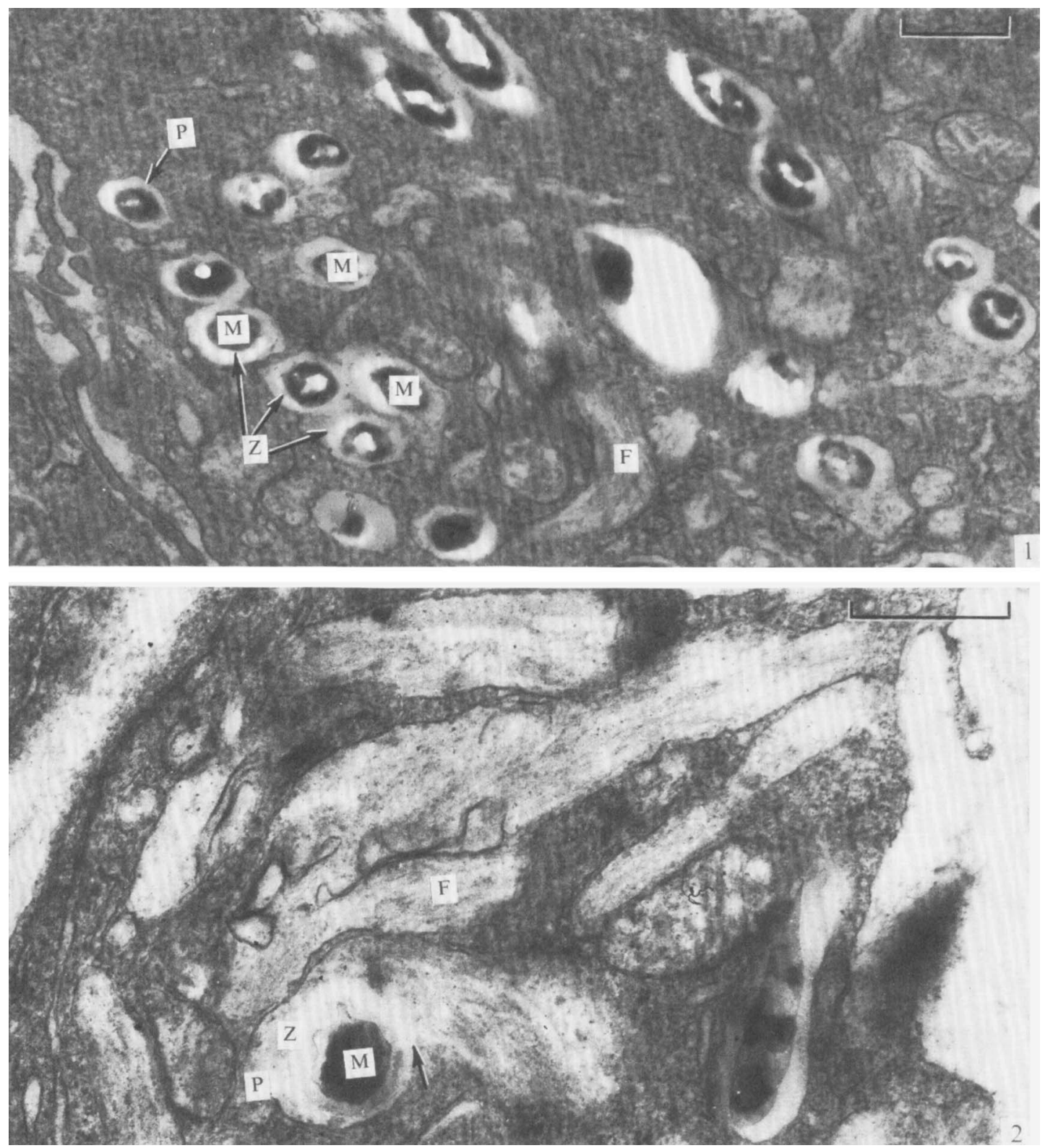

Fig. I-2. Tissues infected with Mycobacterium lepraemurium. Scale bars indicate $0.5 \mu \mathrm{m}$.

Fig. I. Ultrathin section of infected mouse spleen. M, mycobacteria; Z, electron-transparent zone; $\mathrm{P}$, phagosomal membrane; $\mathrm{F}$, large vacuole with fibrillar contents. The 'punched-out' holes in the bacteria are caused by incomplete penetration of the fixative.

Fig. 2. Large vacuoles with fibrillar contents in ultrathin section of liver from infected mouse. Key as in Fig. 1. Fibrillar material and bacterium occur in the same vacuole in one case (arrow). 
Chaput, Michel \& Lederer, I963). Amino acids were estimated in a Beckman automatic analyser.

\section{RESULTS}

\section{Ultrastructure of electron-transparent zone}

In ultrathin sections of livers and spleens of mice infected with Mycobacterium lepraemurium (Fig. I) most of the normal cellular population was replaced by (presumably) phagocytic cells containing mycobacteria. The bacteria were all within intracellular vacuoles, some of which also contained electron-dense material which was probably lysosomal, and were surrounded by the characteristic electron transparent zone. Vacuoles contained one or more bacteria (where many are present in a vacuole the section usually tears).

A second type of vacuole (Fig. I, 2) was common in the infected cells, having nearly electron-transparent contents in which were embedded fibrils arranged roughly parallel. In some cases these vacuoles appeared to be connected to vacuoles containing bacteria, but most were not.

Negatively stained preparations from infected livers contained abundant bacteria, usually featureless apart from the two types of inclusion described by Whitehouse, Wong \& Jackson (197I). Occasionally a damaged bacterium or wall had been penetrated by the stain, and the characteristic 'paired fibrous structures' (Takeya \& Hisatsune, I963) could be seen. These were not visible on intact organisms.

A small proportion of bacteria, especially those occurring in groups, were partly enclosed in fibrillar material of quite different appearance to the bacterial surface structures (Fig. 3). The material seemed to be in 'tapes' which were wrapped longitudinally around the bacteria. Fragments of the material were present in large amounts in the preparations, not attached to bacteria (Fig. 4); the larger fragments had a bacterial outline. At high magnifications the tapes were seen to consist of many fibrils, each about $7 \mathrm{~nm}$ across, arranged parallel to one another (Fig. 5). In the smaller fragments especially the fibrils were partly disarrayed, and the tapes appeared frayed.

In freeze-etched liver occasional bacteria were found that exhibited the pattern of 'paired fibrous structures'. Mostly, however, bacteria-shaped bodies with almost smooth surfaces were found, about $500 \mathrm{~nm}$ in diam. Some of these were broken open to reveal contained bacteria. Structures apparently corresponding to the 'tapes' were seen beside or protruding from beneath the bacteria (Fig. 6) and, often, in seemingly independent vacuoles (Fig. 7). The substructure of $7 \mathrm{~nm}$ fibrils was not resolved.

Suspensions of Mycobacterium lepraemurium prepared for inoculation into animals by the method of Rees et al. (1960) were negatively stained and found to contain the fibrillar material, though rather little remained attached to the bacteria. The ro000 $\times g$ supernatant from the preparation described under Methods contained fibrillar material abundantly, as well as membrane fragments from the host. The latter were dissolved by 8 M-urea, while the fibrillar material floated away from the dense solution and could be collected more or less free from contamination (Fig. 4).

\section{Properties of fibrillar material}

Aqueous suspensions of the material were opalescent with a strong 'swirling flow' effect when a suspension was agitated. Over several days at $4{ }^{\circ} \mathrm{C}$ the suspensions became clearer as the bundles dissociated into smaller groups of fibrils; the dissociation was accelerated by sodium deoxycholate or sodium dodecylsulphate. Freeze-dried suspensions were easily re-suspended in water. 

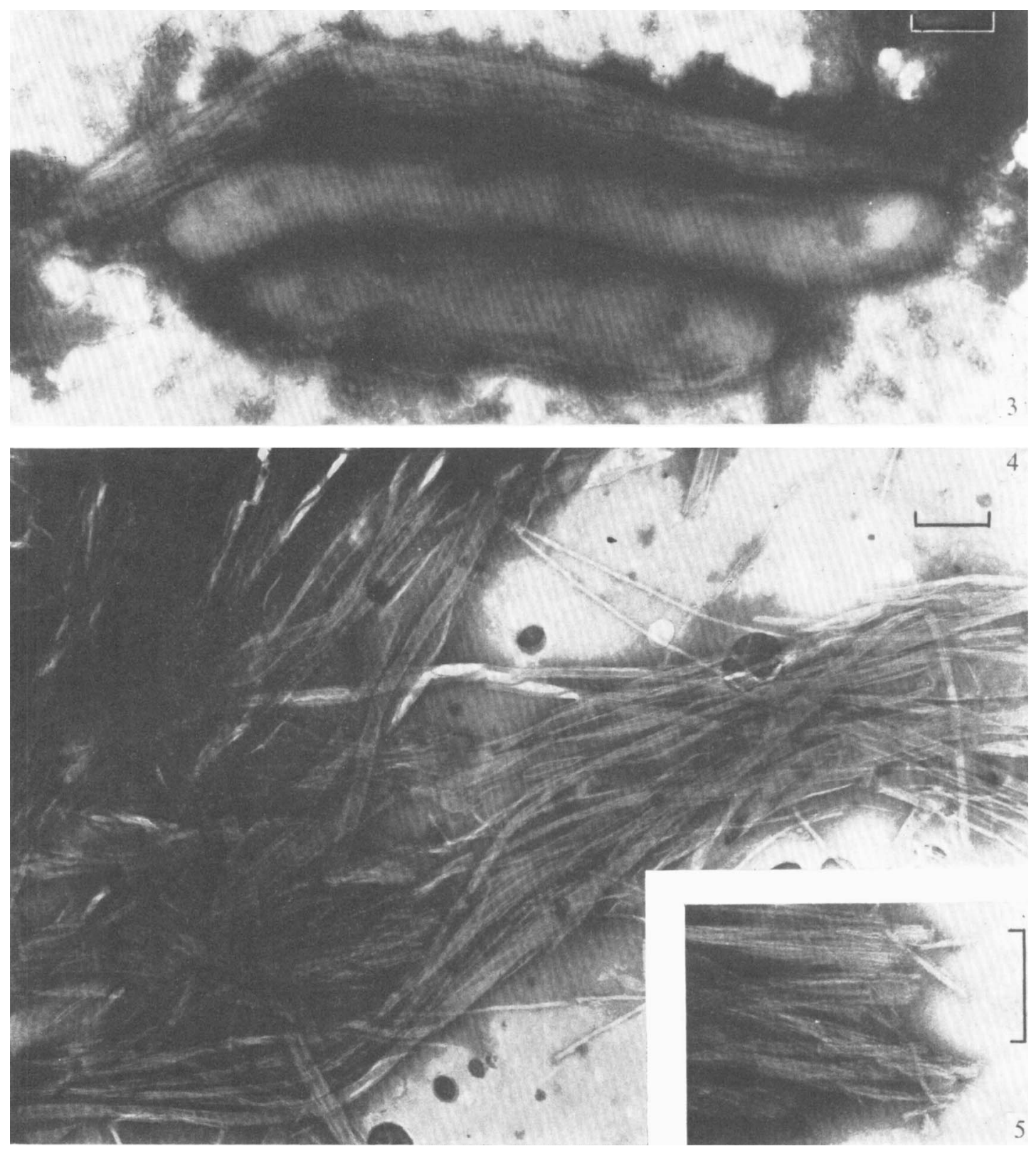

Fig. 3-5. Negatively stained bacteria and fibrillar material. Scale bars indicate $0.2 \mu \mathrm{m}$.

Fig. 3. Mycobacterium lepraemurium from liver of infected mouse, stained with ammonium molybdate. Fibrillar material partly encloses the shorter bacterium.

Fig. 4. Fibrillar material from urea gradient, stained with sodium silicotungstate.

Fig. 5. As Fig. 4, showing substructure of roughly parallel fibrils. 

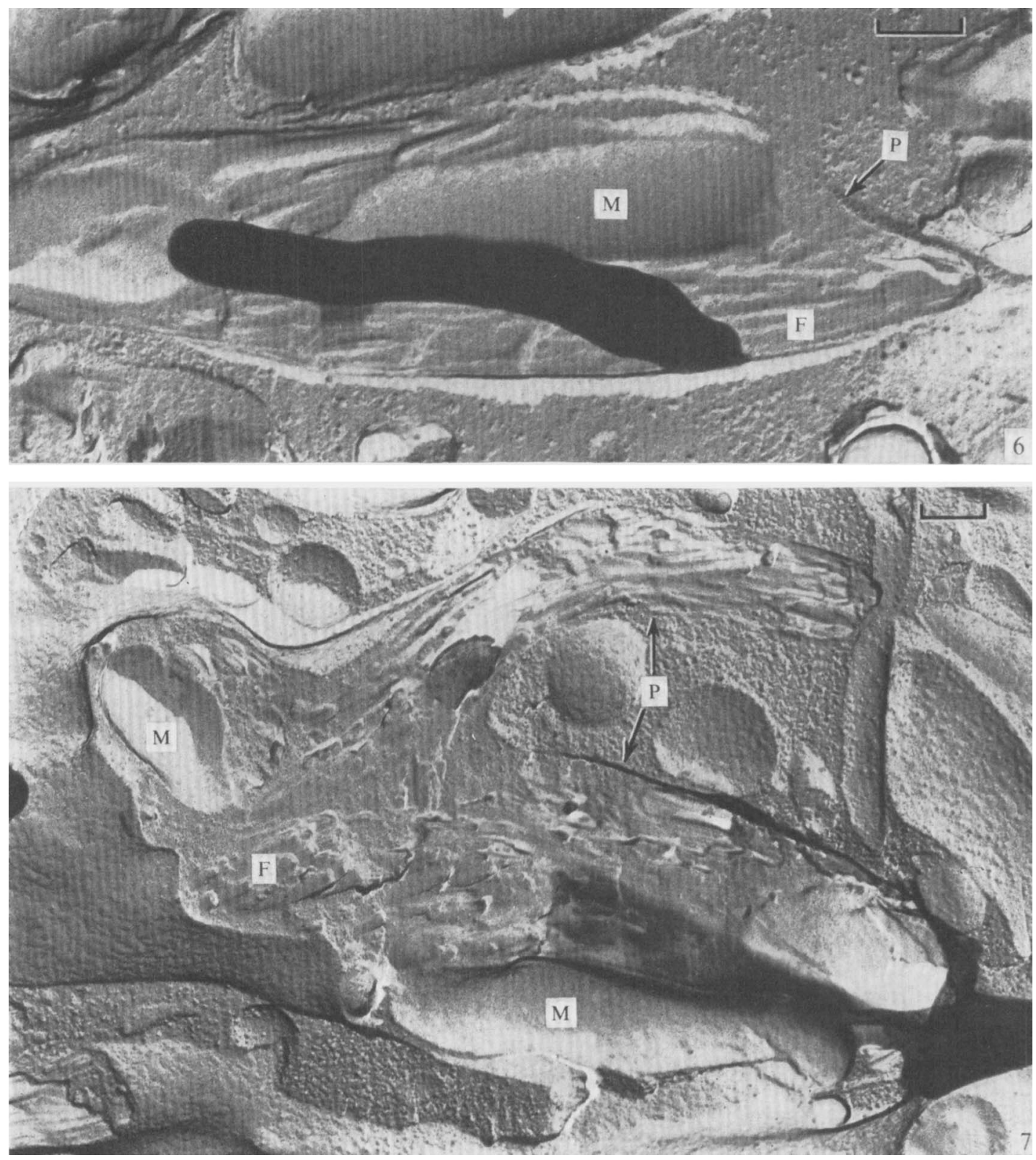

Fig. 6-7. Freeze-etched liver of mice infected with Mycobacterium lepraemurium. The shadowing metal on the replica is dark. Scale bars indicate $0.2 \mu \mathrm{m}$.

Fig. 6. Phagocytic vacuole (P) containing smooth-surfaced bacterium (M) encased in fibrillar material $(\mathrm{F})$. The dark shadow is a mycobacterial cell contaminating the replica.

Fig. 7. Vacuole of complex shape containing fibrillar material apparently almost detached from bacterium. Key as Fig. 6. 
The dried material was mostly soluble in dichloromethane or chloroform. The insoluble part, which could be removed by centrifuging after adding an equal volume of methanol, was 7 to $10 \%$ by weight, and was not investigated further. The chloroform-soluble material contained, in several batches, 25 to $30 \%$ of carbohydrate, consisting of two methyl pentoses. One of these has been identified as 6-deoxytalose by comparison with the authentic sugar, kindly supplied by Dr A. P. MacLennan (identical in three thin-layer systems and in g.l.c. of alditol acetates). Small amounts of rhamnose were also found in some samples.

About $15 \%$ of the chloroform-soluble material was amino acid, consisting of alanine and allothreonine in equimolar amounts, with smaller amounts of phenylalanine, valine and leucine, and the amino-alcohol alaninol. The remainder of the material after hydrolysis was ether-soluble lipid, from which further phenylalanine, leucine and valine could be isolated after a second hydrolysis. The lipid has not been characterized further.

\section{DISCUSSION}

Electron-transparent zones seem to be a characteristic feature of pathogenic mycobacteria growing intracellularly, both in tissues (Yamamoto et al. 1958b; Chapman, Hanks \& Wallace, 1959; Merckx, Brown \& Karlson, 1964; Allen, Brieger \& Rees, 1965; Evans \& Levy, 1972) and in tissue culture (Brown \& Draper, 1970; Armstrong \& Hart, 1971). In the case of Mycobacterium lepraemurium there is some evidence (Allen et al. 1965) that the zone increases with time after infection. The pictures published by these authors show that the embedding process may affect the appearance and probably the width of the zone; it was more conspicuous after Vestopal than after methacrylate embedding. The epoxy-resins commonly used now resemble Vestopal in producing a conspicuous zone (Brown \& Draper, 1970; Armstrong \& Hart, 197I).

Hanks (196I) considered that the zone was a bacterial capsule, an idea strongly supported by the present work. Its featureless appearance may arise because the material is dissolved away during dehydration and embedding. It appears to be a complex bacterial lipid. It has long been considered that the material around Mycobacterium leprae in tissues of patients is a lipid (Nishiura, 1960), and Hasegawa (197I) concluded that the coating around $M$. lepraemurium consisted of lipid and protein.

The vacuoles in infected tissues containing faintly fibrillar material, but not necessarily bacteria, have not been described before. They probably consist of capsular material shed from the bacteria, partly disorganized, and mixed with host protein to produce a visible structure by a sort of natural negative staining process. Apart from the rather tentative connexion provided by this type of vacuole, the freeze-etching results provide a firm bridge between the intractable electron-transparent zone on one hand, and the fibrillar material with a discoverable composition on the other.

Even the limited chemical investigation reported here allows the fibrillar material to be identified as a mycoside of type C. (Chaput et al. I963; Vilkas, Rojas, Das, Wolstenholme \& Lederer, I966; Voiland, Bruneteau \& Michel, 197I). Mycosides (review by Goren, 1972) are glycolipids and peptidoglycolipids found in mycobacteria though not previously in Mycobacterium lepraemurium. Though they are thought to occur near the surface of the bacteria, neither a morphology nor a function has previously been found for them, apart from Lederer's suggestion (Lederer, 1967) that they were concerned with 'Public Relations', which fits the present example very well. Recently the mycosides $\mathrm{C}$ of $M$. avium and $M$. smegmatis have been shown to be receptors for a mycobacteriophage, which indicates that the compound occurs at the periphery of those species also (Furuchi \& Tokunaga, 1972; Goren, McClatchy, Martens \& Brokl, 1972). 
Brown \& Draper (I970) showed that the electron-transparent zone, now identified as a capsule of mycoside, appeared to be a 'spacer' separating the intracellular Mycobacterium lepraemurium from lysosomal enzymes of the host cell. The hydrophobic nature and unusual chemistry of a mycoside would fit it for this function. Production of such a chemical cannot be a sole requirement for success as an intracellular parasite, since several saprophytic mycobacteria synthesize mycosides (Goren, 1972) while $M$. tuberculosis is thought not to have this type of compound at all (Smith, Randall, MacLennan, Putney \& Rao, I960; Walker, Mallmann \& Brunner, I967).

Note added in proof. Dr M. Nishiura has also observed fibrillar structure in freeze-etch electron micrographs of tissues infected with Mycobacterium lepraemurium (B. Thomas, personal communication).

We are grateful to Dr C. Ginger for GLC analysis, Dr S. Jacobs for amino acid analyses and Dr M. Nermut for instruction and discussion on freeze-etching.

\section{REFERENCES}

AlLen, J. M., BRIEGER, E. M. \& ReEs, R. J. W. (I965). Electron microscopy of the host-cell parasite relation in murine leprosy. Journal of Pathology and Bacteriology 89, 30I-306.

Armstrong, J. A. \& Hart, P. D'Arcy (1971). Response of cultured macrophages to Mycobacterium tuberculosis, with observations on fusion of lysosomes with phagosomes. Journal of Experimental Medicine 134, 713-740.

Brown, C. A. \& Draper, P. (1970). An electron-microscope study of rat fibroblasts infected with Mycobacterium lepraemurium. Journal of Pathology 102, 21-26.

Chapman, G. B., Hanks, J. H. \& Wallace, J. H. (1959). An electron microscope study of the disposition and fine structure of Mycobacterium lepraemurium in mouse spleen. Journal of Bacteriology 77, 205-21 1.

Chaput, M., Michel, G. \& Lederer, E. (1963). Structure du mycoside $\mathrm{C}_{2}$ de Mycobacterium avium. Biochimica et biophysica acta 78, 329-34I.

DisCHE, Z. (1962). Colour reactions of 6-deoxy, 3-deoxy and 3,6-dideoxyhexoses. In Methods in Carbohydrate Chemistry, vol I, pp. 50I-503. Edited by R. L. Whistler and M. L. Wolfrom. New York: Academic Press.

DrAPER, P. (1971). The walls of Mycobacterium lepraemurium: chemistry and ultrastructure. Journal of General Microbiology 69, 31 3-324.

DRAPER, P. \& REES, R. J. W. (1970). Electron-transparent zone of mycobacteria may be a defence mechanism. Nature, London 228, 860-86 I.

Dubois, M., Gilles, K. A., Hamilton, J. K., Rebers, P. A. \& Smith, F. (1956). Colorimetric method for determination of sugars and related substances. Analytical Chemistry 28, 350-356.

Evans, M. J. \& Levy, L. (1972). Ultrastructural changes in cells of the mouse footpad infected with Mycobacterium leprae. Infection and Immunity 5, 238-247.

FurUChI, A. \& ToKUNAGA, T. (1972). Nature of the receptor substance of Mycobacterium smegmatis for D4 bacteriophage adsorption. Journal of Bacteriology III, 404-41 I.

Goren, M. B. (1972). Mycobacterial lipids: selected topics. Bacterial Reviews 36, 33-64.

Goren, M. B., MCClatchy, J. K., Martens, B. \& Brokl, O. (1972). Mycosides C: behaviour as receptor site substance for mycobacteriophage D4. Journal of Virology 9, 999-1003.

HaNks, J. H. (196I). The origin of the capsules on Mycobacterium leprae and other tissue-grown mycobacteria. International Journal of Leprosy 29, 172-174.

HASEgaWA, T. (197r). Further electron-microscopic observations of Mycobacterium lepraemurium. Dermatologica 143, 363-367.

Kellenberger, E., Ryter, A. \& SéChaud, J. (1958). Electron microscope study of DNA-containing plasms. II. Vegetative and mature phage DNA as compared with normal bacterial nucleoids in different physiological states. Journal of Biophysical and Biochemical Cytology 4, 671-678.

LEDERER, E. (1967). Glycolipids of mycobacteria and related microorganisms. Chemistry and Physics of Lipids I, 294-315.

Merckx, J. J., Brown, A. L. Jun. \& Karlson, A. G. (1964). An electron-microscopic study of experimental infections with acid-fast bacilli. American Review of Respiratory Diseases 89, 485-496. 
Nishiura, M. (1960). The electron microscopic basis of the pathology of leprosy. International Journal of Leprosy 28, 357-400.

Refs, R. J. W., Valentine, R. C. \& Wong, P. C. (I960). Application of quantitative electron microscopy to the study of Mycobacterium lepraemurium and M. leprae. Journal of General Microbiology 22, 443-457.

Smith, D. W., Randall, H. H., Maclennan, A. P., Putney, R. K. \& Rao, S. V. (1960). Detection of specific lipids in mycobacteria by infrared spectroscopy. Journal of Bacteriology 79, 217-229.

TAKEyA, K. \& Hisatsune, K. (1963). Mycobacterial cell walls. I. Methods of preparation and treatment with various chemicals. Journal of Bacteriology 85, 16-23.

Vilkas, E., Rojas, A., Das, B. C., Wolstenholme, W. A. \& Lederer, E. (1966). Détermination de séquences d'acides aminés dans des oligopeptides par la spectrométrie de masse. VI. Structures du mycoside $\mathrm{C}_{\mathrm{l}}$, peptidoglycolipide de Mycobacterium butyricum. Tetrahedron 22, 2809-2821.

Volland, A., Bruneteau, M. \& Michel, G. (1971). Étude du mycoside $\mathrm{C}_{2}$ de Mycobacterium avium. European Journal of Biochemistry 2I, 285-291.

Walker, R. W., Mallmann, W. L. \& Brunner, J. R. (1967). Type-specific lipids of mycobacteria. American Review of Respiratory Diseases 95, 1065-1067.

Whitehouse, R. L. S., WONG, P. C. \& JACKSON, F. L. (197I). Ultrastructure of Mycobacterium lepraemurium. International Journal of Leprosy 39, $15 \mathrm{I}-163$.

Yamamoto, T., Nishiura, M., Harada, N. \& Imaeda, T. (I958a). Electron microscopy of Mycobacterilum lepraemurium in ultrathin sections of murine leprosy lesions. International Journal of Leprosy 26, III-II4.

Yamamoto, T., Nishiura, M., Harada, N. \& Imafda, T. (1958b). Electron microscopy of ultra-thin sections of lepra cells and Mycobacterium leprae. International Journal of Leprosy 26, I-8. 